\section{Turkish Journal of Botany}

http://journals.tubitak.gov.tr/botany/
Turk J Bot

(2014) 38: 13-21

(c) TÜBİTAK

doi:10.3906/bot-1301-72

\title{
Genome size and phylogenetic relationships between the Tunisian species of the genus Calligonum (Polygonaceae)
}

\author{
Hassen GOUJA ${ }^{1,2,3}$, Alfredo GARCÍA-FERNÁNDEZ ${ }^{3, \star}$, Teresa GARNATJE $^{3}$, Aly RAIES $^{2}$, Mohamed NEFFATI $^{1}$ \\ ${ }^{1}$ Pastoral Ecology Laboratory, Arid Regions Institute, Medenine, Tunisia \\ ${ }^{2}$ Microbial and Biomolecular Laboratory, Faculty of Sciences of Tunis, University of Tunis El-Manar, El-Manar, Tunisia \\ ${ }^{3}$ Botanical Institute of Barcelona (IBB-CSIC-ICUB), Barcelona, Spain
}

Received: 29.01 .2013

- Accepted: 04.09 .2013

- Published Online: 02.01.2014

- Printed: 15.01 .2014

\begin{abstract}
The species of the genus Calligonum L. (Polygonaceae) that appear in Tunisian deserts play an important role in maintaining local ecosystems and supply important natural resources in these regions. In this study, 31 individuals belonging to the 3 hypothetical species of the genus Calligonum (Calligonum arich Le Houér., Calligonum azel Maire, and Calligonum comosum L'Hér.) were collected from 12 populations in 6 localities of the Tunisian desert and examined to assess the relationship between species. Phylogenetic analyses using 1 nuclear (ITS) and 2 plastid regions ( $\operatorname{trn} \mathrm{L}-\operatorname{tr} n \mathrm{~F}$ and $r b c \mathrm{~L})$ and genome size assessments are used in this study to evaluate the relationships between these hypothetical species. C-value results suggest the existence of 3 different species, which is also supported by phylogenetic tree topology. The paraphyletic pattern of $C$. comosum and the plausible origin of $C$. arich from $C$. azel suggest the existence of several mechanisms of isolation and speciation in the Sahara Desert for this genus. Additional studies are necessary to evaluate the population size, demographic tendency, and conservation status of these desert species and their genetic relationships with other congeners.
\end{abstract}

Key words: Calligonum, desert plants, genome size, ITS, $r b c \mathrm{~L}, \operatorname{trnL}-\operatorname{trnF}$, Polygonaceae

\section{Introduction}

Calligonum L. is widely distributed in North Africa, South Europe, and West and Central Asia with approximately 60-80 species (Brandbyge, 1993), with rapid evolution and diversification spots in Asia's deserts (Mabberly, 1990). This accelerated differentiation process has important physiological and morphological consequences, which include the $\mathrm{C} 4$ photosynthesis mechanism, high number of stems, and hybridisation and introgression processes (Pyankov et al., 2000). In the Saharan areas, Calligonum species are dominant perennial shrubs and trees in active sand dunes and in stabilised sand fields in North Africa (Le Houérou, 1959), and they can tolerate extreme drought conditions by the loss of leaves and branches during the driest months (Le Houérou, 1959; Dhief et al., 2009). They appear to be suitable for rehabilitation of degraded lands as well as use in dry land and agroforestry systems, due to their high tolerance to xerophytic conditions (Dhief et al., 2009) and resistance to summer drought (Le Houérou, 1959; Dhief et al., 2009). Furthermore, Liu et al. (2001) and Badria et al. (2007) highlighted the importance of the genus as a source of natural resources, drugs, and antidotes.

\footnotetext{
*Correspondence: alfredo.gar.fer@gmail.com
}

In Tunisia, 3 species of the genus have been described: Calligonum arich Le Houér., C. azel Maire, and C. comosum L'Hér. (Le Houérou, 1959; Pottier-Alapetite, 1979). These species occur in different dune slope positions in the eastern Grand Erg of the Tunisian desert (Le Houérou, 1959). Calligonum comosum and C. azel are leafless shrubs or small trees with white flowers and young succulent branches serving as assimilation organs reaching a height of $>1.5$ to $<2.2 \mathrm{~m}$ (interdune slopes) and $>3.5$ to $<5.5 \mathrm{~m}$ (dune slopes), respectively (Dhief et al., 2012). The young branches of $C$. comosum stems are fragile, articulated, fasciculate, and green, whereas the older ones are white, although certain plasticity has been described for some morphological traits in C. comosum, including stem colour (Taia and Moussa, 2011). Contrarily, the stems of C. azel are mostly buried in the sand and old branches carry a whitish bark peeling off in pieces. Moreover, C. arich is a tree, up to $8 \mathrm{~m}$ tall with red flowers that grow at dune crests, and the older branches carry a brownish-yellow bark peeling off in pieces (Le Houérou, 1959, Dhief et al., 2012). Recent decrease in the population size and changes in the spatial distribution of the 3 studied species can be 
explained by the intensive use of these plants for fuel and charcoal production by local nomadic populations (Le Houérou, 1959; Pottier-Alapetite, 1979).

While 2 of these species are widely accepted, Calligonum azel and C. comosum, the existence of C. arich is doubtful. On the one hand, Le Houérou (1959) and Pottier-Alapetite (1979) considered this species as a Tunisian endemism of the Grand Erg Oriental, together with the databases (International Plant Names Index, 2012; Tropicos, 2012). On the other hand, Greuter et al. (1989) proposed its elimination and, in the current version of the catalogue of flora from Tunisia (Le Floc'h et al., 2010), its existence is doubtful due to the insufficient information available about this species. Previous studies based on morphological and anatomical characters (presence or absence of an ochrea, the tepal arrangement, and anatomy of stomata) have failed to clarify the relationships among these 3 species (Dhief et al., 2009; Le Floc'h et al., 2010) even though cluster analyses carried out with RAPD markers found some genetic differences among the 3 species (Dhief et al., 2011a). These unresolved results lead into the main objective of this study, to evaluate the existence of $C$. arich among the species of the genus Calligonum in Tunisia.
For this goal, we have considered 2 different approaches: describing the phylogenetic relationships among the 3 species of the genus Calligonum; and estimating the differences in the genome size, if any, among the studied species.

\section{Materials and methods}

\subsection{Plant materials}

In this study, we revealed the phylogeny of 31 individuals of 3 Calligonum species (C. arich, C. azel, and C. comosum). Young green branches for each species were collected from 6 sites of the southern desert of Tunisia (Table 1; Figure $1)$. The samples were collected from adult individuals, selecting green healthy branches (without parasitism or signs of drought stress), and were cleaned in the laboratory and kept in a freezer at $-80^{\circ} \mathrm{C}$. In addition, 5 individuals from each species were collected separately from the Kamour site and preserved at $4{ }^{\circ} \mathrm{C}$ in order to measure the genome size. Specimen vouchers of the studied material were deposited in the herbarium of the University of Barcelona (BCN). The classification system used was the catalogue of the Tunisian flora (Le Floc'h et al., 2010).

Table 1. Populations of Calligonum species considered for this study, number of individuals sampled for each population, spatial coordinates, and GenBank accession numbers for the sequences employed.

\begin{tabular}{|c|c|c|c|c|c|c|}
\hline \multirow{2}{*}{ Population } & \multirow{2}{*}{ Species } & \multirow{2}{*}{$\begin{array}{l}\text { Number of } \\
\text { individuals } \\
\text { analysed }\end{array}$} & \multirow{2}{*}{ Coordinates } & \multicolumn{3}{|c|}{ GenBank accession numbers } \\
\hline & & & & ITS & $r b c \mathrm{~L}$ & $\operatorname{trn} \mathrm{F}$ \\
\hline \multirow[t]{3}{*}{ Kamour } & C. comosum & 2 & $\begin{array}{l}32^{\circ} 33^{\prime} 60^{\prime \prime} \mathrm{N} \\
09^{\circ} 27^{\prime} 57^{\prime \prime} \mathrm{E}\end{array}$ & KC585426-27 & KC585458-59 & KC585490-91 \\
\hline & C. azel & 3 & & KC585435-37 & KC585467-69 & KC585499-501 \\
\hline & C. arich & 5 & & КС585444-48 & KC585476-80 & KC585508-12 \\
\hline Douz & C. comosum & 1 & $\begin{array}{l}33^{\circ} 14^{\prime} 20^{\prime \prime} \mathrm{N} \\
09^{\circ} 20^{\prime} 13^{\prime \prime} \mathrm{E}\end{array}$ & KC585419 & KC585451 & KC585483 \\
\hline El Ouera & C. comosum & 3 & $\begin{array}{l}32^{\circ} 40^{\prime} 18^{\prime \prime} \mathrm{N} \\
10^{\circ} 35^{\prime} 41^{\prime \prime} \mathrm{E}\end{array}$ & KC585420-22 & KC585452-54 & KC585484-86 \\
\hline \multirow[t]{2}{*}{ J'bil } & C. comosum & 2 & $\begin{array}{l}32^{\circ} 59^{\prime} 20^{\prime \prime} \mathrm{N} \\
09^{\circ} 00^{\prime} 29^{\prime \prime} \mathrm{E}\end{array}$ & KC585417-18 & KC585449-50 & KC585481-82 \\
\hline & C. arich & 2 & & KC585441-43 & KC585473-75 & KC585505-07 \\
\hline \multirow[t]{3}{*}{ El Borma } & C. comosum & 3 & $\begin{array}{l}31^{\circ} 38^{\prime} 40^{\prime \prime} \mathrm{N} \\
09^{\circ} 27^{\prime} 44^{\prime \prime} \mathrm{E}\end{array}$ & KC585428-30 & КС585460-62 & KC585492-94 \\
\hline & C. azel & 2 & & KC585433-34 & КС585465-66 & КС585497-98 \\
\hline & C. arich & 3 & & KC585438-40 & KC585470-72 & KC585502-04 \\
\hline \multirow[t]{2}{*}{ Tiert } & C. comosum & 3 & $\begin{array}{l}30^{\circ} 47^{\prime} 06^{\prime \prime} \mathrm{N} \\
10^{\circ} 16^{\prime} 54^{\prime \prime} \mathrm{E}\end{array}$ & KC585423-25 & KC5854555-57 & KC585487-89 \\
\hline & C. azel & 2 & & KC585431-32 & КC5854563-64 & KC585495-96 \\
\hline
\end{tabular}




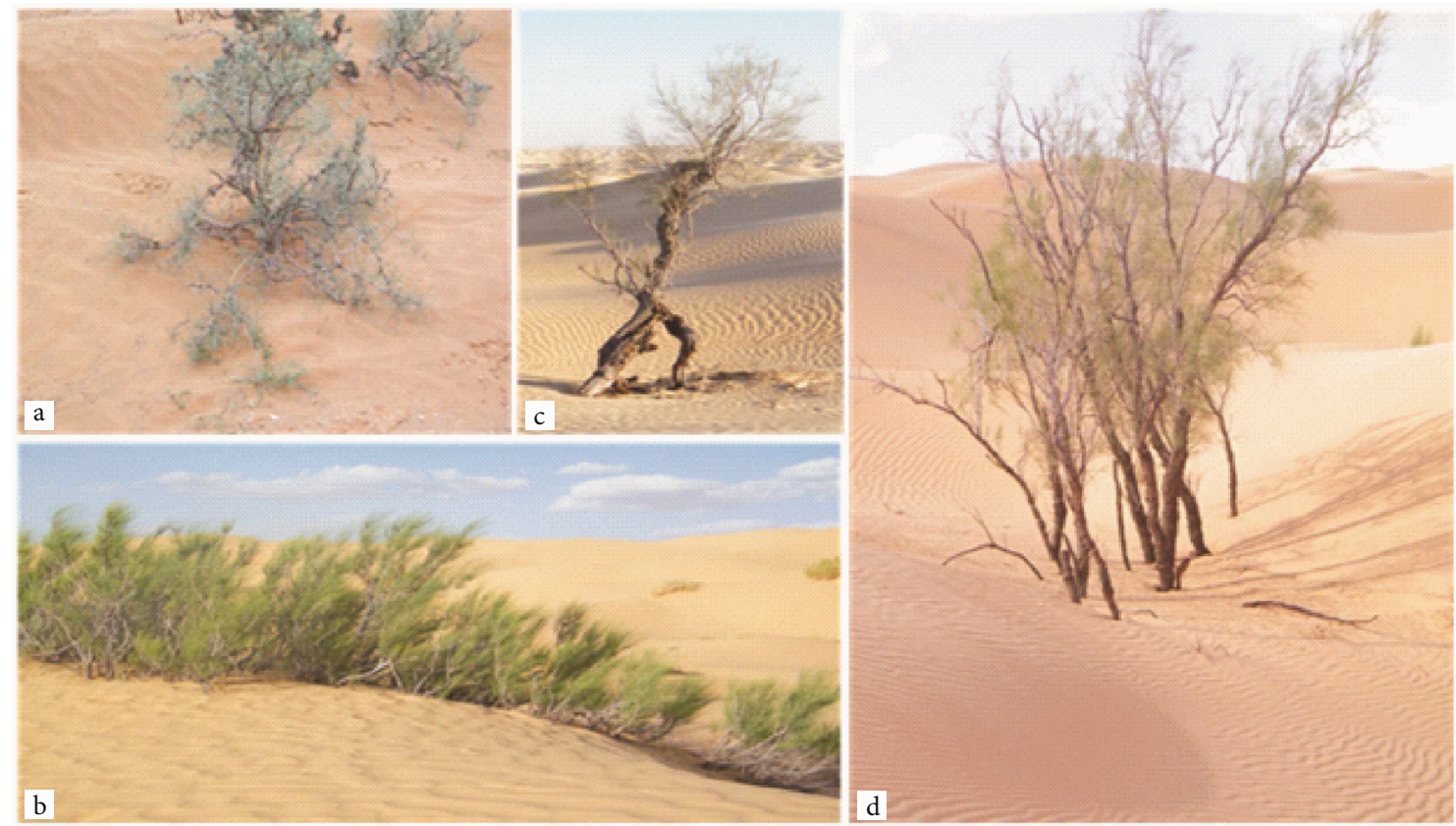

Figure 1. Photographs of the study area depicting: a- Calligonum comosum in interdune, b- C. azel in dune slope, c, d- C. arich in dune crest.

\subsection{DNA extraction procedure, PCR protocol,} amplification, and sequencing

Genomic DNA was extracted following the CTAB method described by Doyle and Doyle (1990) with some modifications. DNA extractions were checked by electrophoresis using $0.8 \%$ agarose gel and DNA concentration was estimated at an optical density of 260 nm using a NanoDrop 1000 spectrophotometer (Thermo Scientific Inc., Wilmington, DE, USA).

A preliminary screening was carried out to find optimal and variable nuclear (ITS) and chloroplast $(t r n \mathrm{~F}, r b c \mathrm{~L}, n d h \mathrm{~F}$, $p s b \mathrm{~A}-t r n \mathrm{H}, m a t \mathrm{~K})$ regions, based on previous studies in the genus Calligonum and family Polygonaceae (e.g., Sanchez et al., 2009; Tavakkoli et al., 2010; Tian et al., 2011; Sun and Zhang, 2012). DNA amplification reactions of $n r$ DNA ITS (ITS1, 5.8S, and ITS2) and 2 plastid fragments (trnL-F and $r b c \mathrm{~L}$ regions) were performed in a $25-\mu \mathrm{L}$ reaction mixture, according to Tavakkoli et al. (2010), containing $2.5 \mu \mathrm{L}$ of a 50 -ng genomic DNA template, $12.8 \mu \mathrm{L}$ of sterile water, $2.5 \mu \mathrm{L}$ of $2 \mathrm{mM} \mathrm{MgCl}_{2}, 2.5 \mu \mathrm{L}$ of $10 \mathrm{X}$ Gene Taq universal buffer, $2.5 \mu \mathrm{L}$ of $2.5 \mathrm{mM}$ dNTP mixture, $1 \mu \mathrm{L}$ of each primer $(5 \mathrm{pmol} / \mu \mathrm{L})$, and $0.2 \mu \mathrm{L}$ of AmpliTaq DNA polymerase at $5 \mathrm{U} / \mu \mathrm{L}$ (Applied Biosystems, Carlsbad, CA, USA). The nrDNA (ITS1, 5.8S, and ITS2) was amplified using the universal ITS1-ITS4 pair of primers (White et al., 1990). The polymerase chain reaction (PCR) conditions, as performed in a thermocycler (S 1000 Thermal Cycler, BioRad Laboratories, Inc., Hercules, CA, USA), were 2 min at $94{ }^{\circ} \mathrm{C} ; 40$ cycles consisting of denaturation for $1 \mathrm{~min}$ at 94
${ }^{\circ} \mathrm{C}$, annealing for $40 \mathrm{~s}$ at $53{ }^{\circ} \mathrm{C}$, and elongation for $1 \mathrm{~min}$ at $72{ }^{\circ} \mathrm{C}$; and a final extension for $7 \mathrm{~min}$ at $72{ }^{\circ} \mathrm{C}$. The plastid $\operatorname{trn} \mathrm{L}-\operatorname{trn} \mathrm{F}$ region was amplified using the universal " $\mathrm{c}$ " and "d" primers of Taberlet et al. (1991) under the following conditions: $2.5 \mathrm{~min}$ at $95{ }^{\circ} \mathrm{C}$ for initial denaturation, followed by 38 cycles of $1 \mathrm{~min}$ at $95{ }^{\circ} \mathrm{C}, 45 \mathrm{~s}$ at $53^{\circ} \mathrm{C}$ for annealing, 2 min at $72{ }^{\circ} \mathrm{C}$ for extension, and then a final 7 -min incubation at $72^{\circ} \mathrm{C}$. The $r b c \mathrm{~L}$ gene was amplified by PCR using primers $r b c \mathrm{~L}-1 \mathrm{~F}$ and $r b c \mathrm{~L}-724 \mathrm{r}\left(3 \mathrm{~min}\right.$ at $94^{\circ} \mathrm{C}$, follow by 38 cycles of $1 \mathrm{~min}$ of denaturation at $94^{\circ} \mathrm{C}, 50 \mathrm{~s}$ of annealing at $50{ }^{\circ} \mathrm{C}, 1 \mathrm{~min}$ of extension at $72{ }^{\circ} \mathrm{C}$, and then 8 min for final extension at $72{ }^{\circ} \mathrm{C}$, as per Chase et al. (1993)). All amplified products (plastid and nuclear) were checked by electrophoresis on a $1.2 \%$ agarose gel $(\mathrm{w} / \mathrm{v})$. Each region was sequenced with the BigDye Terminator Cycle Reaction Kit v. 3.1 (PE Biosystems, Foster City, CA, USA) using the same primers as described for PCR. Nucleotide sequencing was carried out at the Centres Cientifics i Tecnològics of the University of Barcelona on an ABI PRISM 3730XL DNA analyser (PE Biosystems).

\subsection{Sequence alignment and phylogenetic analyses}

The $\operatorname{trn} \mathrm{L}-\operatorname{trn} \mathrm{F}, r b c \mathrm{~L}$, and ITS sequences were edited and aligned using BioEdit v. 7.1.3.0 (Hall, 1999) followed by manual adjustment. Alignment of each dataset required the introduction of numerous single and multiple-base indels (insertions/deletions). Positions of indels were treated as missing data for all datasets (Tables 1 and 2). For both nuclear and chloroplastic matrices, Calligonum junceum and Calligonum arborescens were considered 
Table 2. Summary of the number of polymorphic sites, potential informative sites, and indels for each region (ITS, trnF, and $r b c \mathrm{~L}$ ).

\begin{tabular}{llll}
\hline & Polymorphic sites & Potential informative sites & Indels \\
\hline ITS & 155 & 120 & 79 \\
$t r n \mathrm{~F}$ & 0 & 0 & 0 \\
$r b c \mathrm{~L}$ & 2 & 2 & 4 \\
\hline
\end{tabular}

as outgroups (GenBank accession numbers: C. junceum trnL-trnF JQ009289, rbcL GQ206217, ITS AB542774; C. arborescens trnL-trnF JQ009294, rbcL EU840536, ITS JN 187105; Sanchez et al., 2009; Tavakkoli et al., 2010; Tian et al., 2011; Sun and Zhang, 2012).

Combination of ITS and plastid datasets was assessed using the incongruence length difference (ILD) test (Farris et al., 1994) implemented in PAUP (Swofford, 2003). The test was performed using the heuristic search option involving simple addition sequence and tree bisectionreconnection (TBR) branch swapping with 1000 replicates and excluding invariant characters.

Maximum parsimony analyses were carried out using PAUP. The heuristic search option was employed, using TBR branch swapping with 1000 replications of random addition sequence and excluding uninformative characters. Full heuristic search was used for branch support with 1000 bootstrap replicates each with a simple addition sequence.

Complementary, independent Bayesian phylogenetic analysis was performed in MrBayes 3.1.2 (Huelsenbeck et al., 2001) using a GTR $+\mathrm{G}$ model determined from jModeltest v. 0.1.1 (Posada, 2008) under the Akaike information criterion (AIC; Akaike, 1979), to ascertain phylogenetic relationships. The Markov chain Monte Carlo (MCMC) sampling approach was used to calculate posterior probabilities (PPs). Four consecutive MCMC computations were run for 1,000,000 generations, with tree sampling every 100 generations. Data from the first 1000 generations were discarded as the burn-in period. PPs were estimated through the construction of a $50 \%$ majority rule consensus tree. The output trees were edited with FigTree v. 1.3.1 (Rambaut, 2006).

Finally, a neighbour-net analysis was carried out considering the uncorrected p-distance between individuals and the same outgroup species from the Bayesian analyses, using SplitsTree 4.10 (Huson and Bryant, 2006). Branches' support was tested using bootstrapping with 1000 replicates.

\subsection{Flow cytometry measurements and analysis}

Five individuals were analysed by flow cytometry of each species of Calligonum from the locality of Kamour. Fresh young leaves were used in this analysis and each sample was measured 2 times. The standard method used for DNA content measurement by flow cytometry was as described by Garnatje et al. (2004). Petunia hybrida Vilm. 'PxPc6' $(2 \mathrm{C}=2.85 \mathrm{pg}$; Marie and Brown, 1993) and Lycopersicon esculentum Mill. 'Montfavet 63-5' (2C = 1.99 pg; Catrice et al., 2006) were used as the internal standards and were firstly analysed separately to locate their peak positions. Leaf tissue of each Calligonum sample (about $50 \mathrm{~mm}^{2}$ ) and the internal standard (approximately half the quantity) were chopped with a razor blade in a plastic petri dish in $600 \mu \mathrm{L}$ of LB01 buffer (8\% Triton X-100) (Dolezel et al., 1989), supplemented with $100 \mu \mathrm{g} / \mathrm{mL}$ ribonuclease A (RNase A, Boehringer, Meylan, France). To eliminate cell debris, nuclei were filtered 2 times through a $30-\mu \mathrm{m}$ nylon filter; $60 \mu \mathrm{g} / \mathrm{mL}$ propidium iodide was subsequently added (Invitrogen Corporation, Carlsbad, CA, USA). Samples were kept on ice for $10 \mathrm{~min}$ before measurement. Fluorescence analysis was carried out using an Epics XL flow cytometer (Coulter Corporation, Hialeah, FL, USA) at the Centres Científics i Tecnològics of the University of Barcelona.

One-way ANOVA analysis was carried out to test the differences in the genome size values, if any, among the 3 studied species. This analysis was performed with Stata 10.0 (Stata Corporation, College Station, TX, USA).

\section{Results}

\subsection{Phylogenetic analyses}

The ILD test did not show significant incongruence between plastid and ITS regions $(\mathrm{P}=0.98)$, which allowed the combination of both datasets. The aligned matrix with 31 accessions containing the 3 considered regions is 1749 bp long ( $620 \mathrm{bp}$ of ITS, $522 \mathrm{bp}$ of $\operatorname{trnL} \mathrm{L}-\mathrm{trnF}$, and $607 \mathrm{bp}$ of $r b c \mathrm{~L}$ ), of which 122 are potentially informative, being the ITS regions most useful to the phylogenetic reconstruction. Table 2 details the number of indels and polymorphic and informative sites for each region in the 3 species.

The tree obtained with Bayesian inference is shown in Figure 2. Calligonum arich shows statistical support for a monophyletic independent branch $(\mathrm{PP}=100 \%)$; meanwhile, $C$. azel shares a common origin with $C$. 


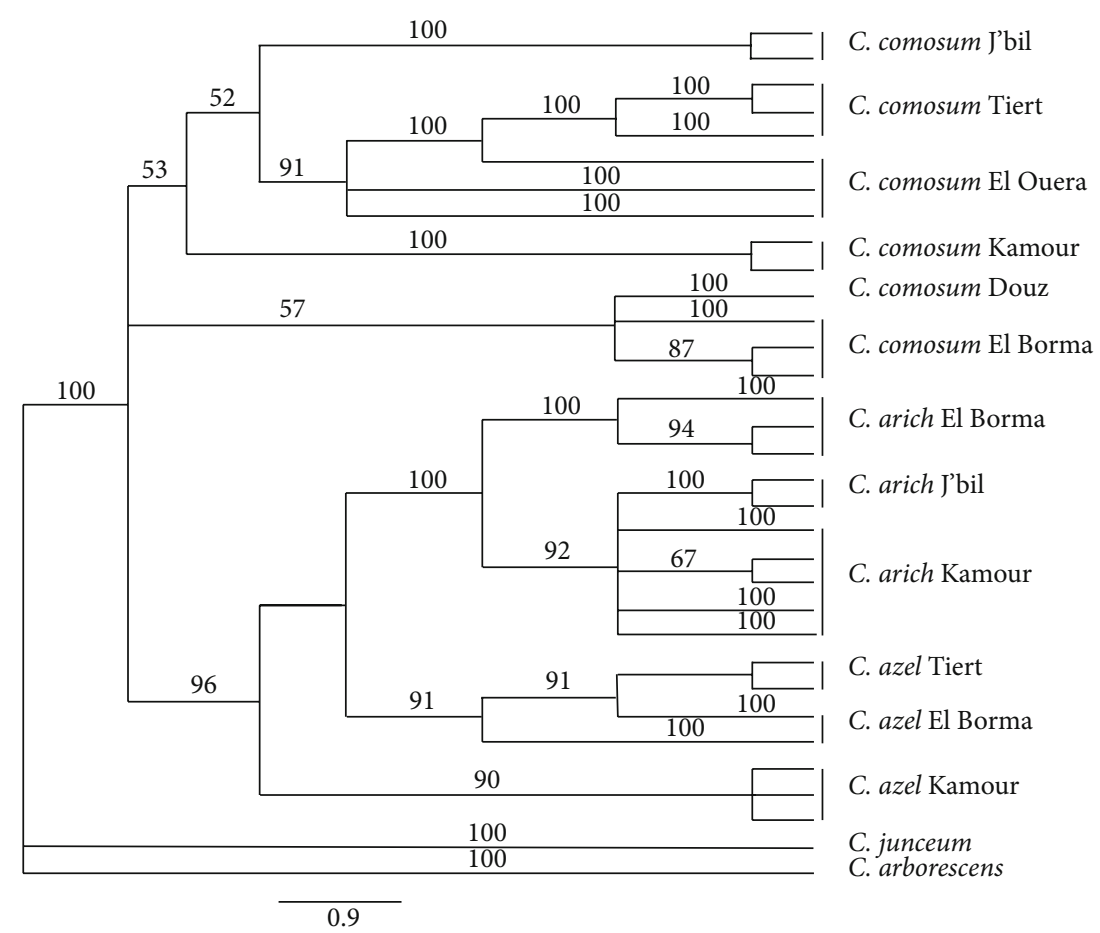

Figure 2. Majority rule consensus tree from Bayesian inference based on sequences from the merged dataset of the 3 regions (ITS, $\operatorname{trn} \mathrm{L}-\mathrm{F}$, and $r b c \mathrm{~L}$ ). The numbers above the branches are the PPs.

arich (but lacks statistical support). Calligonum comosum shows a paraphyletic pattern with no significant value in the branches (Figure 1). Similar results to those shown by Bayesian analysis in the strict consensus tree were obtained with the maximum parsimony approach and bootstrapping coefficients (data not shown). Figure 3 shows the obtained neighbour-net. All populations from the same species are clustered in the same group with significant statistical support.

\subsection{Genome size}

The $2 \mathrm{C}$ values obtained for the tree of Calligonum species ranged from $2.30 \pm 0.10 \mathrm{pg}$ for C. azel to $2.45 \pm 0.07 \mathrm{pg}$ for C. arich and $4.68 \pm 0.17 \mathrm{pg}$ in C. comosum. Half-peak coefficient of variation (HPCV) values were lower than $5 \%$ in all cases, which indicates the high quality of the analyses. Slight significant differences $(\mathrm{F}=4.03, \mathrm{P}=0.04)$ were obtained comparing the genome size values $(1 \mathrm{C} x)$, assuming C. arich to be diploid.

\section{Discussion}

\subsection{Phylogenetic analyses of Calligonum from Tunisia}

Previous studies have suggested the existence of the 3 species of the genus Calligonum in Tunisia, even though some differences have also been found between the different analyses carried out. On the one hand, the cluster analysis developed by Dhief et al. (2012) based on morphological traits showed C. comosum and C. azel grouped together (similarity of 29\%), sharing some phenotypic traits (e.g., the stem, flower and fruit colour), whereas C. arich remained isolated. On the other hand, using some chemical descriptors (essential oils), C. arich and C. comosum were grouped with a similarity of $38 \%$ without C. azel (Dhief et al., 2011b). Both analyses of morphological diversity and of chemical polymorphism showed different grouping patterns. However, results from phylogenetic analyses support an alternative scenario. Nonmonophyletic clades were obtained for $C$. comosum in the phylogenetic reconstructions (Figure 2). Our work, together with previous studies carried out with polymorphic markers (RAPD; Dhief et al., 2011a), has shown higher values of genetic diversity in this species than in the other 2, which might support partially the tree topology and the network pattern obtained (Figures 2 and 3 ) in this study. The wider distribution of C. comosum along the Tunisian desert and other regions (Koller, 1956), its interdune position, the phenotypic plasticity described (Taia and Moussa, 2001), and its high production of flowers and fruits (Dhief et al., 2009, 2012) may have facilitated sexual reproduction, the gene flow between populations, or potential genomic processes such as population isolation, introgression, 


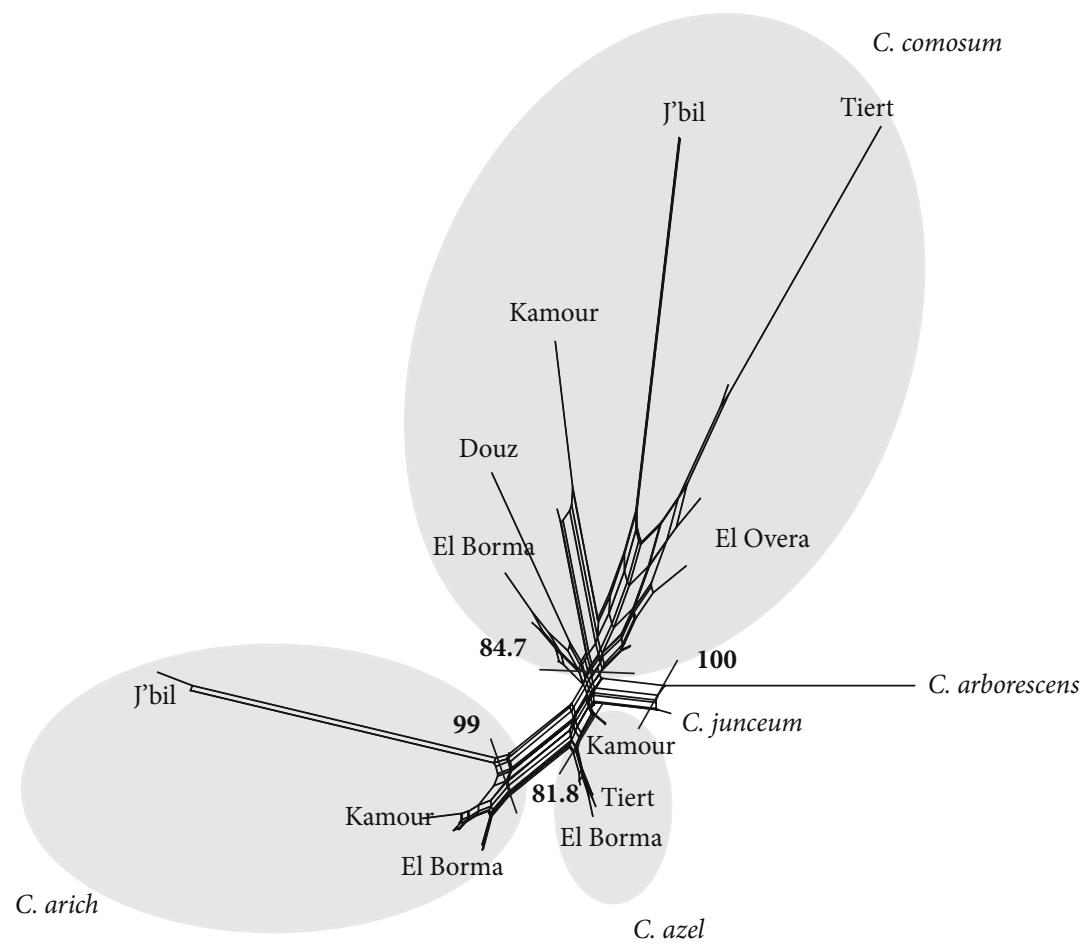

Figure 3. Neighbour-net analyses based on uncorrected p-distances. Numbers indicate bootstrap values over 1000 replicates. Populations of the same species are grouped in the same grey cluster.

or hybridisation at the contact zones with other taxa. Hybridisation processes between current species (or common ancestors) might also explain the polyphyletic pattern found in C. comosum, but there is no evidence in DNA sequences. Calligonum comosum exhibits a nuclear DNA amount higher than those of the other species and the genome size of this taxon is nearly double the $2 \mathrm{C}$ value of C. azel and C. arich. Considering that the nuclear DNA amount is not purely duplicated during chromosome doubling (Levy and Feldman, 2002), we might hypothesise that $C$. azel or $C$. arich could be involved in the origin of the tetraploid C. comosum. Despite the lack of support from the phylogenetic tree (Figure 2), this species is well defined by the previous karyological (Ferchichi, 1997) and cytogenetic characteristics or the neighbour-net approach (Figure 3). Furthermore, its tetraploid karyotype would be prone to accumulation of mutations (Otto, 2007), which facilitate the divergence and the genetic differences between populations (Figures 2 and 3), which may occur more frequent in nuclear than in chloroplast regions (Table 2).

All populations belonging to $C$. arich merged into a well-supported clade ( $\mathrm{PP}=100 \%, \mathrm{BS}=99 \%$; see Figures 2 and 3, respectively) but the relationships with C. azel are not clear. In this context, a pair of hypotheses are possible: the first is that $C$. azel could have originated from C. arich through a polyploidisation process. The genome size values (doubled in C. azel compared to C. arich) could also support this evidence. The second hypothesis bears the inclusion of $C$. arich into C. azel, making it monophyletic, but neither the previous morphological traits and chemical studies (Dhief et al., 2009, 2012) nor the genome sizes agree with this possibility. Since the taxonomical status of C. arich could have important implications in the policy of conservation, further karyological, cytogenetic, and phylogenetic analyses with additional genetic markers would be necessary to establish the chromosome number or cytogenetically characterise and chronologically date $C$. arich.

\subsection{Calligonum genome size}

The present study showed the first measures of $C$ values for the genus Calligonum (see RGB Kew Plant DNA C-values, Bennett and Leitch, 2010). The small coefficients for HPCV obtained support the reliability of the measurements done, although intrapopulation variability in the genome size and its correlation to certain factors have already been described (e.g., García-Fernández et al., 2012; Tabur et al., 2012) and could not be discarded in certain Calligonum populations. Measures with flow cytometry might have some technical and logistical problems for these 
species (maybe associated with the presence of alkaloids, polysaccharides, and secondary metabolites (Liu et al., 2001)), due to the difficult of obtaining fresh material from desert populations and their preservation for measurement (Doležel et al., 2007).

The significant statistically differences obtained suggest the existence of 3 independent species of the genus Calligonum growing in Tunisia. Mao et al. (1983) proposed $x=9$ as the basic chromosome number for the genus. Furthermore, Ferchichi (1997) carried out chromosomal counting in C. comosum $(2 n=36$, tetraploid) and C. azel $(2 n=18$, diploid $)$, which revealed the different ploidy levels. Other cytogenetic processes that modify the chromosome number, such as mixoploidy or aneuploidy, have been described in some Calligonum species and are frequent in other genera of the tribe Atraphaxideae (Xinmin et al., 2009). All these processes might have played relevant roles in the evolution of the genome size, highlighting their key role during genome duplication and polyploidization throughout plant evolution (Soltis and Soltis, 1999). During these processes, genome size must be doubled together with the chromosome number, although a certain quantity of DNA could be eliminated (Leitch and Bennett, 2004) to avoid potential mutations that are frequent in polyploids (Sharma and Sen, 2002).

Polyploids are very common in angiosperm species (Soltis and Soltis, 1999) and might favour the colonisation of new and harsh environments (St Clair and Howe, 2011; te Beest et al., 2012). In spite of the relevant physiological cost of the increase in genome size (i.e. Gregory, 2001; Otto, 2007), the rise in the number of chromosomes supposes potential new alleles and an increase of the genetic variation may play its role in selection under new

\section{References}

Akaike H (1979). A Bayesian extension of the minimum AIC procedure of autoregressive model fitting. Biometrika 66: 237-242.

Badria FA, Ameen M, Aki MR (2007). Evaluation of cytotoxic compounds from Calligonum comosum L. growing in Egypt. Z Naturforsch C 62: 656-660.

Bennett M, Leitch I (2010). Angiosperm DNA C-values database. Website: http://data.kew.org/cvalues/CvalServlet?querytype $=1$ [accessed 1 September 2013].

Brandbyge J (1993). Polygonaceae. In: Kubitzki K, Rohwer JC, Bittrich V, editors. The Families and Genera of Vascular Plants, Vol. 2. Berlin: Springer-Verlag, pp. 531-544.

Catrice O, Coba de la Peña T, Brown SC (2006). Applications en biologie végétale: contraintes, succès, espoirs. In: Ronot $\mathrm{X}$, Grunwald D, Mayol JF, Boutonnat J, editors. La Cytométrie en conditions and stress factors (Otto, 2007). The tetraploid chromosome number of $C$. comosum might have been involved in its ability to colonise different areas of the Tunisian desert. Similar responses to the high levels of stress and chromosome evolution have been found in other genera of the tribe Polygonaceae, such as Fagopyrum Mill. (Yamane and Ohnoshi, 2003) and Rumex L. (Stehlik and Blattner, 2004)

\subsection{Concluding remarks}

Some cytogenetic and phylogenetic evidence for the independence of the 3 Calligonum species in the Tunisian desert are reported in this study. These results are very helpful to preserve, promote, and find the appropriate strategy for the use of these species in future programs of rehabilitation of degraded Tunisian areas. Further studies are needed to establish the relationships among these 3 species and the related congeneric ones.

\section{Acknowledgements}

This work was subsidised by MICINN (Spanish Government; Project CGL2010-22234-C02-01 and 02). We thank the technical staff of the Range Ecology Laboratory, Arid Lands Institute of Medenine, who helped us to develop the fieldwork, and the staff of the Laboratory of Biosystematics and Molecular Systematics at the Botanical Institute of Barcelona for their support and help. We also want to express our gratitude to Jaume Comas and Ricard Àlvarez for technical support in flow cytometry. We also thank Alastair Plant for language assistance. AG-F benefited from a postdoctoral contract (Project CGL201022234-C02-01). We also acknowledge the commentaries of the 3 anonymous reviewers on previous versions of the manuscript.

Flux. Paris: Tec \& Doc - Lavoisier, pp. 235-253 (in French).

Chase MW, Soltis DE, Olmstead RG, Morgan D, Les DH, Mishler BD, Duvall MR, Price RA, Hills HG, Qiu YL et al. (1993). Phylogenetics of seed plants: an analysis of nucleotide sequences from the plastid gene $r b c \mathrm{~L}$. Ann Mo Bot Gard 80: $528-580$

Dhief A, Gorai M, Aschi-Smiti S, Neffati M (2009). Comparative phenological and water potential patterns of three Calligonum species in the eastern great Erg of Tunisia. Flora 204: 581-592.

Dhief A, Guasmi F, Triki T, Neffati M, Samira AS (2011a). Natural genetic variation in Calligonum Tunisian genus analyzed by RAPD markers. Afr J Biotechnol 10: 9766-9778.

Dhief A, Neffati, M, Aschi-Smiti S (2012). Taxonomic study of the Tunisian Calligonum genus using the morphological and anatomical traits. IJBBS 1: 018-033. 
Dhief A, Zouari S, Abdellaoui R, Aschi-Smiti S, Neffati M (2011b). Comparative study of chemical composition of the essential oils from three Calligonum species growing-wild in Tunisian desert. J Essent Oil Bear Pl 14: 11-22.

Doležel J, Binarova P, Lucretti S (1989). Analysis of nuclear-DNA content in plant-cells by flow-cytometry. Biol Plant 31: 113120.

Doležel J, Greilhuber J, Suda J (2007). Estimation of nuclear DNA content in plants using flow cytometry. Nat Protoc 2: 22332244.

Doyle JJ, Doyle JL (1990). Isolation of plant DNA from fresh tissue. Focus 12: 13-15.

Farris JS, Källersjö M, Kluge AG, Bult C (1994). Testing significance of incongruence. Cladistics 10: 315-319.

Ferchichi A (1997). Contribution à l'étude caryologique, caryosystématique, morphologique et écologique de la flore de la Tunisie présahariene. Tunis, Tunisia: Université de Tunis - El Manar (in French).

García-Fernández A, Iriondo J, Vallés J, Orellana J, Escudero A (2012). Ploidy level and genome size of locally adapted populations of Silene ciliata across an altitudinal gradient. Plant Syst Evol 298: 139-146.

Garnatje T, Vallès J, Garcia S, Hidalgo O, Sanz M, Canela MÁ, SiljakYakovlev S (2004). Genome size in Echinops L. and related genera (Asteraceae, Cardueae): karyological, ecological and phylogenetic implications. Biol Cell 96: 117-124.

Gregory TR (2001). Coincidence, coevolution, or causation? DNA content, cell size, and the C-value enigma. Biol Rev Camb Philos 76: 65-101.

Greuter W, Burdet HM, Long G (1989). Med-Checklist 4. Dicotyledones (Lauraceae-Rhamnaceae). Geneva: Conservatoire et Jardin bontaniques de la Ville de Genève.

Hall TA (1999). BioEdit: A user-friendly biological sequence alignment editor and analysis program for Windows 95/98/ NT. Nuclear Acids Symp Ser 41: 95-98.

Huelsenbeck JP, Ronquist F, Nielsen R, Bollback JP (2001). Bayesian inference of phylogeny and its impact on evolutionary biology. Science 294: 2310-2314.

Huson DH, Bryant D (2006). Application of phylogenetic networks in evolutionary studies. Mol Biol Evol 23: 254-267.

International Plant Names Index (2012). Website: http://www.ipni. org [accessed 9 April 2012].

Koller D (1956). Germination regulating mechanisms in some desert seeds III. Calligonum comosum L'Hér. Ecology 37: 430-433.

Le Floc'h E, Boulos L, Vela E (2010). Catalogue synonymique commenté de la Flore de la Tunisie. Tunis, Tunisia: Banque Nationale de Genes (in French).

Le Houérou H (1959). Recherches écologiques et floristiques sur la végétation de la Tunisie méridionale. Algiers: Institut des Recherches Sahariennes (in French).
Leitch IJ, Bennett MD (2004). Genome downsizing in polyploid plants. Biol J Linn Soc 82: 651-663.

Levy AA, Feldman M (2002). The impact of polyploidy on grass genome evolution. Plant Physiol 130: 1587-1593.

Liu XM, Zakaria MNM, Islam MW, Radhakrishnan R, Ismail A, Chen HB, Chan K, Al-Attas A (2001). Anti-inflammatory and anti-ulcer activity of Calligonum comosum in rats. Fitoterapia 72: 487-491.

Mabberly DJ (1990). The Plant Book. Cambridge: Cambridge University Press.

Mao ZM, Yang G, Wang CG (1983). Studies on chromosome numbers and anatomy of young branches of Calligonum of Xinjiang in relation to the evolution of some species of the genus. Acta Phytotaxon Sin 21: 44-49.

Marie D, Brown SC (1993). A cytometric exercise in plant DNA histograms, with 2C values for 70 species. Biol Cell 78: 41-51.

Otto SP (2007). The evolutionary consequences of polyploidy. Cell 131: 452-462.

Posada D (2008). jModelTest: Phylogenetic model averaging. Mol Biol Evol 25: 1253-1256.

Pottier-Alapetite G (1979). Flore de la Tunisie, AngiospermesDicotylédones: Apétales-Dialypétales. Tunis, Tunisia: Publications Scientifiques Tunnisiennes.

Pyankov VI, Gunin PD, Tsoog S, Black CC (2000). C4 plants in the vegetation of Mongolia: their natural occurrence and geographical distribution in relation to climate. Oecologia 123: $15-31$.

Rambaut A (2006). FigTree 1.3.1. Edinburgh: Edinburgh University Press.

Sanchez A, Schuster TM, Kron KA (2009). A large-scale phylogeny of Polygonaceae based on molecular data. Int J Plant Sci 170: 1044-1055.

Sharma A, Sen S (2002). Chromosome Botany. Enfield, NH, USA: Science Publishers Inc.

Soltis DE, Soltis PS (1999). Polyploidy: recurrent formation and genome evolution. Trends Ecol Evol 14: 348-352.

St Clair JB, Howe GT (2011). Strategies for conserving forest genetic resources in the face of climate change. Turk J Bot 35: 403-409.

Stehlik I, Blattner F (2004). Sex-specific SCAR markers in the dioecious plant Rumex nivalis (Polygonaceae) and implications for the evolution of sex chromosomes. Theor Appl Genet 108: 238-242.

Sung YX, Zhang ML (2012). Molecular phylogeny of tribe Atraphaxideae (Polygonaceae) evidenced from five cpDNA genes. J Arid Land 4: 180-190.

Swofford DL (2003). PAUP*: Phylogenetic Analysis Using Parsimony, Version 4.0 b10. Sunderland, MA, USA: Sinauer Associates.

Taberlet P, Gielly L, Pautou G, Bouvet J (1991). Universal primers for amplification of three non-coding regions of chloroplast DNA. Plant Mol Biol 17: 1105-1109. 
Tabur S, Civelek Ş, Öney S, Yılmaz Ergün ŞB, Kurşat M, Türkoğlu İ (2012). Chromosome counts and karyomorphology of some species of Artemisia (Asteraceae) from Turkey. Turk J Bot 36: 235-242.

Taia WK, Moussa SAI (2011). Phenotypic variations in Calligonum comosum L'Hér. (Polygonaceae) grown in Al-Nefud Desert in Saudi Arabia. J Sci Res 3: 421-435

Tavakkoli S, Shahrokh Kazempour O, Maassoumi AS (2010). The phylogeny of Calligonum and Pteropyrum (Polygonaceae) based on nuclear ribosomal DNA-ITS and chloroplast trnL-F sequences. Iran J Biotechnol 8: 7-15.

te Beest M, Le Roux JJ, Richardson DM, Brysting AK, Suda J, Kubešová M, Pyšek P (2012). The more the better? The role of polyploidy in facilitating plant invasions. Ann Bot 109: 19-45.

Tian X, Luo J, Wang A, Mao K, Liu J (2011). On the origin of the woody buckwheat Fagopyrum tibeticum (Parapteropyrum tibeticum) in the Qinghai-Tibetan Plateau. Mol Phylogen Evol 61: $515-520$
Tropicos.org (2012). Missouri Botanical Garden. Website: http:// www.tropicos.org [accessed 9 April 2013].

Wang R (2007). $C_{4}$ plants in the deserts of China: occurrence of $\mathrm{C}_{4}$ photosynthesis and its morphological functional types. Photosynthetica 45: 167-171.

White T, Bruns T, Lee S, JT (1990). Amplifications and direct sequencing of fungal ribosomal RNA genes for phylogenetics. In: Innis M, Gelfand D, Sninsky J, White T, editors. PCR Protocols: A Guide to Methods and Applications, San Diego, CA, USA: Academic Press, pp. 318-322.

Xinmin T, Liu R, Tian B, Liu J (2009). Karyological studies of Parapteropyrum and Atraphaxis (Polygonaceae). Caryologia 62: 261-266.

Yamane K, Ohnoshi O (2003). Morphological variation and differentiation between diploid and tetraploid cytotypes of Fagopyrum cymosum. Fagopyrum 20: 17-25. 